\title{
Luba Tomcikova,
}

Ph.D., University of Presov, Slovakia

iD ORCID ID, 0000-0001-7722-7578

email: luba.tomcikova@unipo.sk

Nella Svetozarovova,

Ph.D., University of Presov, Slovakia

ORCID ID, 0000-0003-4899-2013

email: nella.svetozarovova@unipo.sk

Jana Coculova,

Ph.D., University of Presov, Slovakia

(iD) ORCID ID, 0000-0001-6105-3614

email: jana.cocul'ova@unipo.sk

Correspondence author: luba.tomcikova@unipo.sk

\section{CHALLENGES AND PRIORITIES IN TALENT MANAGEMENT DURING THE GLOBAL PANDEMIC CAUSED BY COVID-19}

Abstract. The paper deals with the talent management issue as one of the effective human resource management practices during the global pandemic caused by COVID-19 and points to the main challenges and priorities in the research area. Talent management has undergone a dynamic development in recent years. It has recently become a frequently discussed concept among business and academics alike and one of the priorities of the modern management of all companies. The paper also presents the results of research carried out on a sample of 137 human resources managers. Respondents who participated in the questionnaire survey are human resources managers in companies operating in the Slovak Republic at national and international markets. Data were collected using the online questionnaire. For the research, two research hypotheses were established. The hypotheses aimed to determine whether there are statistically significant relationships between the scale of talent recruitment and selection process over the past year; the change in the management and organizational style of the company during the COVID-19 pandemic; the existence of the statistically significant relationship between the budget allocated to talent management and headhunting practices over the last year. The hypotheses were verified using correlation analysis and the methods of inductive statistics. Testing the statistically significant relationships verified hypothesis H1. It confirmed the existence of statistically significant relationships between the scale of the talent recruitment and selection process over the past year and the change in management and organization of the company during the COVID-19 pandemic. The hypothesis $\mathrm{H} 2$ was rejected. It stated the absence of statistically significant relationships between the budget for talent management in the organization during the COVID-19 pandemic and the competition for qualified talent for the last year. The questionnaire survey results pointed how human resources managers in companies operating in the Slovak Republic perceive the situation associated with the current COVID-19 pandemic. The findings identified the pandemic impact on talent management and how human resources managers see human resource management's future and priorities.

Keywords: human resources management, pandemic crisis, talents, talent management.

Introduction. Regarding the global COVID-19 pandemic, human resources are important to the company's success than ever before. Companies which produce new knowledge are successful. It stands to state that the bearers of knowledge capital are talented employees with above-average intelligence, those who actively develop their knowledge, skills, and abilities. According to a Dun and Bradstreet survey (Nangia and Mohsin, 2020), the best practice in human resource management is talent management,

Cite as: Tomcikova, L., Svetozarovova, N., \& Coculova, J. (2021). Challenges and Priorities in Talent Management During the Global Pandemic Caused by COVID-19. Marketing and Management of Innovations, 2, 94103. http://doi.org/10.21272/mmi.2021.2-08

94 

Pandemic Caused by COVID-19

followed by employee engagement, training, and employee development. Hanif and Shao (2013), Nangia and Mohsin (2020) stated that various human resource management practices, such as recruitment and training, performance management, succession planning, and others, play a key role in implementing effective talent management practices. Thus, talent management plays a significant role in motivating and retaining talented employees. Notably, talent is the driving force of the company's success. Talent management is becoming an increasingly important tool for gaining a lasting competitive advantage through human capital (Tarique and Schuler, 2010). Besides, it is the case given the current economic downturn and the volatile market environment during the COVID-19 global pandemic when companies have to respond to several challenges and set new priorities.

Literature Review. As a result of the global COVID-19 pandemic, companies worldwide are currently operating in a highly volatile business environment. Recently, the COVID-19 pandemic has created demanding conditions for human resources managers. In the context of changes worldwide due to the pandemic, organizations need to respond and adapt to the alterations and manage the workforce accordingly (Carnevale and Hatak, 2020; Gigauri, 2020). Organizations strive to be proactive in this everchanging and unpredictable world. A report from the KPMG survey (2020) highlights the impact of COVID19 on the global economy. It pointed out that the huge market shock provoked a reduction in production. Thus, the organizations have suffered from a shortage of inputs and other raw materials. The outbreak of the pandemic has led to market tensions. When the new coronavirus began to spread, it was expected to spread only in China. However, it later spread throughout the world and resulted in a global pandemic. The pandemic brought about social distancing and economic upheaval (Elliot, 2020). Many companies were affected, no matter their size or location.

Camacho (2020) stated that coronavirus impacted company management, especially the organizational structure and human resource management, including talent management. Thus, more employers demand new skills and abilities from their employees to cope with the changing business environment (in connection with the process of globalization, or deglobalization, intensifying competition, the outbreak of the pandemic). Therefore, the problem with the lack of talented employees is becoming increasingly prominent. To be more effective in implementing changes, human resource managers need to review their talent management techniques and align them with the organization's new strategic goals and specify new areas' priorities. In the studies (Sparrow and Makram 2015; Collings and Mellahi, 2009), the authors stated that talent management becomes a critical factor in the success of any organization. Thus, talent and highly effective employees have become a scarce commodity worldwide. The advent of the knowledge economy and the new generation of the workforce means that traditional human resource management is not a good tool, as its activities are focused on a large, homogeneous, and employerdependent workforce. The new workforce is less experienced, more globally-oriented, highly virtual, and very diverse. Its autonomy and independence require introducing a new generation of human resource management techniques - global talent management. Nilsson and Eilstrom (2012) stated that the success of an organization is achieved only by identifying, recruiting, managing, and retaining high-performing or talented individuals. Large international companies recognize that they could make their company more competitive through talent and adapt to changes more quickly (Richbell et al., 2010).

Brad (2019) pointed to seven major global trends and recommendations that affect the human resource management process and the talent management process as follows:

1. Accepting the mixed workforce that is more diverse than ever; considering women raising children who want to return to work and retirees whose age is increasing, and many want to work again and benefit.

2. Retaining talented employees; applying technologies and virtual collaboration could reduce costs or increase efficiency, strengthen relationships, and improve collaboration.

3. Modernizing the recruitment and selection processes; using modern and effective methods and ways of recruiting and selecting talents; doing what other employers do not; ensuring that candidates have 
a positive experience of the recruitment process at the first interaction with the company.

4. Using appropriate methods and ways of training employees. Nowadays, online education is a popular way of education (especially in times of pandemics), while personal education has its irreplaceable place in the training process.

5. Focusing on employee behavior and attitudes rather than qualifications. Despite the candidates' expertise and skills, probably, they have no soft skills, cannot adapt to the corporate culture, or the attitude is out of the company line.

6. Developing a strategic plan for retaining the best talent. Managers need to understand why people stay, why they leave and familiarize themselves with the situations that affect these factors. Business conditions have got more challenging.

Nangia and Mohsin (2020) proposed a framework that could serve as a basic model for talent management assistance to various companies which may encounter many business problems during the global crisis triggered by the COVID-19 pandemic (Table 1). The authors examined talent management practices in the IT industry during a global pandemic. They created a model of priorities based on talent management practices identified during the COVID-19 global pandemic. Besides, Nangia and Mohsin (2020) pointed out that companies could also apply the established framework of important and less important priorities from other sectors of the economy in times of pandemic.

Table 1. The framework of talent management priorities during the COVID-19 pandemic High priority talent management practices

1. Employee engagement and retention practices

- Creative employee engagement strategies: constant communication with employees through cloudbased platforms, virtual team meetings, creating hobby clubs, etc.

- Creating a central register with detailed profiles of all employees for driving engaging discussions with clients.

- Virtual celebration of events creative compensations and benefits schemes: providing additional benefits to employees working from home.

- Creative practices to ensure the physical and mental well-being of employees.

2. Employee development practices

- Everything gone virtual, creative upskilling sessions, virtual learning and development programs, crossfunctional training, and exposure.

- $\quad$ Building on internal efficiencies.

- Virtual employee life cycle from onboarding to exit.

Low priority talent management practices

1. Talent acquisition

Virtual interviews, virtual hiring, strengthening internal talent acquisition team to cut down on outsourcing costs of consultants.

Sources: developed by the authors based on (Nangia and Mohsin, 2020).

Talent management ensures that suitable people with the right skills are in the proper job position. Their careers also act as a stimulating factor in improving the employment situation inside and outside the business entity. Talent management provides the right processes and tools to support and strengthen the position of managers. Business entities that want to invest in talent management could expect a high rate of return on their investment. It depends, in particular, on a sufficiently motivated workforce that contributes to the overall productivity (Sonnenberg et al., 2013; Coculova et al., 2020). While businesses tend to recover in cycles, talent has to be positioned to be productive during and immediately after the crisis phase, as soon as organizations identify it. It brings to some basic principles of talent management during a pandemic, which organizations should adopt to cope with and overcome a crisis posed by unforeseen events. Mathur and Parashar (2020), Peirson and Paycor (2020) summarized them as follows: 
A. Set projects to follow short-term goals and refining the strategies to meet medium-term goals. While it is essential to ensure that talent has the right tools at home to maintain engagement and collaboration, business requirements might be subject to a long-term review of policies and organizational proposals. This impact may vary depending on the industry, geography, cash flow, and size of operations. In the short term (0-30 days), employees could develop project management practices that would help them navigate the change management. In this regard, it is necessary to create a revised strategic plan for the next 6 months with defined results. In these situations, the organizations should follow the philosophy that focused first on making changes and improvements to existing ways of working and increasing capabilities to improve business impact, not on quantitative optimization through radical measures. In the short term, new opportunities could also arise concerning working from home to develop competencies and skills.

B. Manage collective and individual productivity and performance - crises tend to test the performance management and talent assessment strategies of most progressive organizations. It is mainly because business continuity comes first, and optimization and reduction in working conditions usually become automatic responses to the fear of the unknown. While it is necessary to plan business algorithms, organizations should not forget about their high-performing talent and focus on maintaining momentum. Their response to the crisis determines how well the organization could handle complex problems and the recovery phase. Although collective productivity remains of great importance during a pandemic, organizations need to adequately differentiate and reward talented employees who have achieved great results in the pre-crisis phase. If they fail to do so, they could lose these employees as the market stabilizes. Therefore, it is important to ensure that talent is well managed, evaluated, engaged, and developed according to the essential requirements.

C. Teamwork and communication - managers lead open communication and strengthen trust in teams. Successful organizations tend to take a «we are together» approach and ensure that employees are being communicated with. There is transparency in every step an organization takes, and vulnerabilities an organization faces are portrayed positively, especially in remote work scenarios (including external dynamics).

D. Adaptive and intuitive leadership - unexpected events of this magnitude present significant challenges for high-performing talent who are expected to show empathy, navigate the business environment, anticipate future progress, and create innovative solutions that benefit everyone. It becomes the most important immediate starting point, as crises do not come with instruction and involve resolving many ambiguities, questions, uncertainties, planning, and change management. Identifying and developing such talent as part of business continuity planning could help overcome even the most challenging problems.

E. Role modification, talent identification, and talent building - crises encourage capacity building and role regrouping. Organizations may see these situations as opportunities to rethink tasks entrusted to certain job positions and promote greater opportunities for training and developing their talents.

By summarizing, elaborating on, and implementing these five principles of talent management during a pandemic, it is possible to create a functioning model of talent management policy in the organization during each crisis, not only during a pandemic. The participation of risk management, crisis management, and change management is essential in such cases. Caligiuri et al. (2020) pointed out that future research should examine whether different configurations of the talent portfolio should be emphasized in the context of global uncertainty and whether different types of human capital could contribute differently to organizational resilience.

Methodology and research methods. The aim of the paper was to identify challenges and priorities in talent management during the global COVID-19 pandemic. The study examined statistically significant relationships between the scale of the talent recruitment and selection process over the last year. In turn, 

Pandemic Caused by COVID-19

the changes in business management and organization during the COVID-19 pandemic were considered. Moreover, the paper aimed to find out statistically significant relationships between the budget allocated to talent management and the hunt for qualified talent over the last year. Respondents who participated in the questionnaire survey are human resources (HR) managers in companies operating in the Slovak Republic. Data were collected using the online questionnaire. Data were processed using descriptive statistics and then examined for statistically significant relationships using inductive statistics. A total of 137 HR managers participated in the questionnaire survey. Questionnaire items focused on the size, form, and business scope of the company, issues that significantly affect human resources management and talent in the current situation - a global pandemic caused by the virus COVID-19 of 2020. For the needs of research and the fulfillment of the main goal, the following research hypotheses were formulated:

H1: There is a statistically significant relationship between the scale of the talent recruitment and selection process over the past year and the change in how the company is managed and organized during the COVID-19 pandemic.

H2: There is a statistically significant relationship between the budget allocated to talent management at the time of the COVID-19 pandemic and the talent hunting over the last year.

Results. The questionnaire survey aimed to determine how the COVID-19 pandemic affects HR and talent management in organizations that operate in the Slovak Republic. The results of the questionnaire survey present several essential findings. The results show how HR managers perceive the situation associated with the current COVID-19 pandemic, how this pandemic affects the management of individual talent management practices, what they consider current trends and priorities in the field, and how HR managers predict the future of HRM priorities. The questionnaire survey involved $137 \mathrm{HR}$ managers who work in small and medium-sized enterprises (69.34\%) and large enterprises (30.66\%). The majority of respondents $(81.75 \%)$ work in HR positions for 1 to 3 years. These are mainly companies operating in the domestic business environment (65\%). The remaining $35 \%$ of HR managers out of 137 work in multinational companies, which also have their operations in the Slovak Republic.

Impact of the COVID-19 pandemic on the organization. As the situation caused by the new type of coronavirus affects many areas of working life and the associated management of individual HRM practices, organizations should be prepared to respond quickly to change and have their action plans prepared beforehand. The respondents answered whether their organization was negatively affected by the COVID-19 pandemic (on a scale of 1 - I strongly agree with the statement to 5 - I strongly disagree). The results show that $51 \%$ of respondents strongly agree that their organization is negatively affected by the COVID-19 pandemic, $27 \%$ partially agree with the statement, while the remaining $22 \%$ of HR managers disagree.

Changes in the way the organization is managed and organized during the COVID-19 pandemic. As it is possible to monitor impacts and changes brought by the COVID-19 pandemic, such as the significant shift towards virtual teams and work from home, HR managers answered whether they are experiencing changes in company management and organization processes in the pandemic. Table 2 presents the results. Thus, more than half of the respondents agree that the impact of the pandemic leads to changes in the way the company is managed and organized. $3 \mathrm{HR}$ managers strongly disagree with this statement.

The extent of the talent recruitment and selection process in the context of the COVID-19 pandemic. The aim was to learn more about the extent of the recruitment process regarding talented employees, as changes did not spare this field of human resources during the pandemic. As reported (Blatch-Jones et al., 2020), nowadays, the recruitment process involves digital tools (online or by telephone). The most commonly used digital recruitment tool is database screening, which is considered the most effective. Respondents had the opportunity to express their views on the recruitment and selection process on a scale from 1 - very wide to 5 - no recruitment and selection took place. The results showed that most companies did not recruit any employees ( $70 \%$ of companies) at the time of the pandemic. 
L., Tomcikova, N., Svetozarovova, J., Coculova. Challenges and Priorities in Talent Management During the Global Pandemic Caused by COVID-19

Table 2. Changes in the way the organization is managed and organized during the pandemic

\begin{tabular}{lcccc}
\hline \multicolumn{1}{c}{ The scale - changes in the way the organization } & $\mathbf{N}$ & Percentage & Valid \% & Cumulative \% \\
\hline 1 - I strongly agree & 46 & 33,60 & 33,60 & 33,60 \\
2 - I agree & 70 & 51,10 & 51,10 & 84,70 \\
3 - I don't know & 0 & 0,00 & 0,00 & 84,70 \\
4 - I disagree & 18 & 13,10 & 13,10 & 97,8 \\
5 - I strongly disagree & 3 & 2,20 & 2,20 & 100,00 \\
Total & 137 & 100,00 & 100,00 & \\
\hline
\end{tabular}

Sources: developed by the authors.

Competition overqualified talent for the last year. With the continuing uncertainty regarding the management and organization of the company caused by the COVID-19 pandemic, organizations must ensure that their employees have the skills and knowledge necessary for the introduction and implementation of new ways and procedures. That is why talented employees are key to success, and, as Styblo (2010) states, talents are the driving force of success. One of the sub-objectives of the paper was to examine whether the competition for qualified talent has increased or decreased. Respondents expressed their degree of agreement or disagreement with the statement «competition for qualified talent has increased in the last year» and to mark their answers on the interval scale from 1 - strongly agree to 4 - strongly disagree. Results show that in the surveyed companies that operate in the territory of the Slovak Republic, the competition for qualified talent has increased in the last year, i.e., $25.55 \%$ of HR managers fully agree with the statement and $70.75 \%$ of respondents agree. Only $3.70 \%$ of respondents completely disagree with the given statement. Thus, the competition for qualified talent has decreased in the last year.

Talent management budget: attracting, recruiting and selecting, developing, and retaining talent. During the pandemic, many companies are facing recessions. Many of them need to effectively manage or reduce labor and talent costs while ensuring that the company develops and retains the talented employees required to recover from the recession. Therefore, the partial aim of the questionnaire was to determine the budget allocated for talent management in the surveyed organization on the interval scale 1 - budget increased, 2 - budget remained the same, 3 - budget decreased. It stands to state that the budget for talent management (including activities related to the attraction of talents, recruitment, identification, retention of talents, their development) has mainly not changed. Notably, it remained the same in $65.70 \%$ of companies. The budget increased in $12.40 \%$ of companies and decreased in $21.90 \%$ of companies.

The next part of the online questionnaire focused on the future of priority management in human resources. Beno (2008) stated that in addition to the current and significant shift to work from home and online work, other influences would affect the organization's management. According to Yildirim and Korkmaz (2017), the effectiveness of human resource management and the development of teamwork are crucial factors in the company's success. Figure 1 outlines the questionnaire survey results. Thus, the priority in HRM is the transformation of talent practices. Then, investments follow this in future training and retraining of employees. The least essential priority in HR management is the redesign of the organizational structure. 
L., Tomcikova, N., Svetozarovova, J., Coculova. Challenges and Priorities in Talent Management During the Global Pandemic Caused by COVID-19

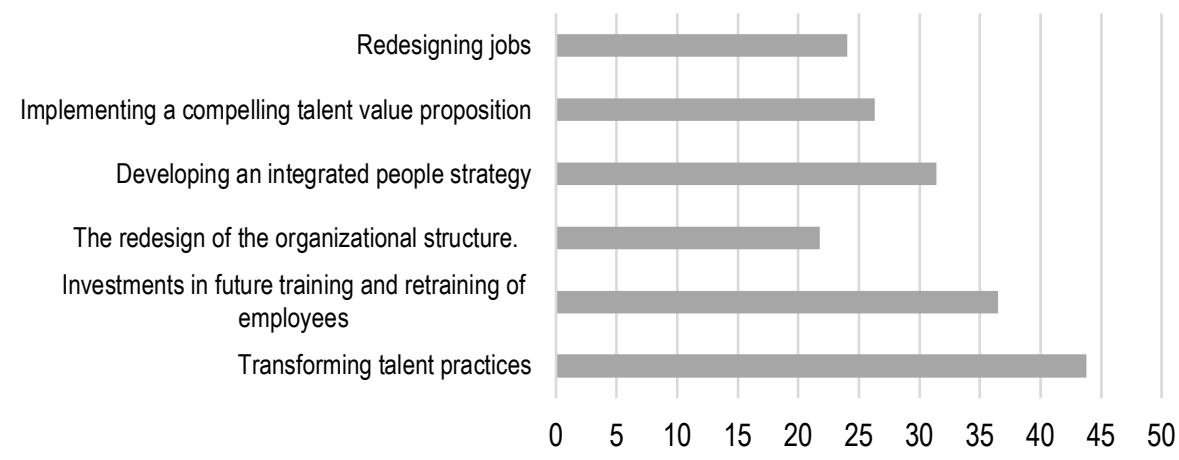

Figure 1. Future work priorities in the field of human resources management (as a percentage) Sources: developed by the authors.

This study involved the correlation analysis for solving the research problem and testing the hypothesis $\mathrm{H} 1$ and H2. According to Ostertagova (2013), the correlation analysis determines the degree of strength with which the dependence between various interfering side factors manifests itself. The correlation analysis emphasizes the strength (intensity) of the relationship between the variables. The Spearman rank correlation coefficient rS (most commonly used rank correlation coefficient) measures the association of any statistical dependence that is monotonic. This coefficient could be used to determine the degree of intensity (association) of the correlation of the two statistical features wherever we have statistical features measured on scales that allow both examined features to be arranged in two orders. Subsequently, the Kendall rank correlation coefficient was used. The coefficient measures the strength of the dependence between two ranked variables and provides a nonparametric test of independence (i.e., the coefficient significance test). Kendall's tau expresses the difference between the probabilities that the values of two variables are in the same order against the probability that the values are not in the same order (Ostertagova, 2013). Concerning the effort aimed at verifying the existence of a statistically significant relationship between the scale of the talent recruitment and selection process and the change in the way the company is managed and organized during the COVID-19 pandemic, a null and alternative hypothesis H1 were formulated:

$\mathrm{HO}$ (null hypothesis): $\theta=\theta 0$

$\mathrm{HO}$ : There is no statistically significant relationship between the scale of the talent recruitment and selection process over the past year and the change in how the company is managed and organized during the COVID-19 pandemic.

$\mathrm{H} 1$ (alternative hypothesis): $\theta=\theta$

$\mathrm{H} 1$ : There is a statistically significant relationship between the scale of the talent recruitment and selection process over the past year and the change in how the company is managed and organized during the COVID-19 pandemic.

Table 3 presents the results regarding the testing hypothesis.

In this case, the correlation analysis was performed using two correlation coefficients. The Spearman coefficient takes values from the interval $<-1,1\rangle$. It is interpreted analogously as an ordinary selection correlation coefficient. Values approaching 0 indicate a weaker dependence of the variables. Values closer to 1 or -1 indicate a stronger dependence. Extreme value 1 corresponds to a complete match of two orders, extreme value -1 to exactly the opposite order. Herewith, positive values mean that the variables tend to change in the same direction, negative values in different directions (Ostertagova, 2013). Spearman's coefficient shows a high dependence between the scale of the talent recruitment and selection process 
L., Tomcikova, N., Svetozarovova, J., Coculova. Challenges and Priorities in Talent Management During the Global Pandemic Caused by COVID-19

over the past year and the change in how the company is managed and organized during the COVID-19 pandemic $(0,507)$.

Table 3. Results of testing H1 (values of correlation coefficients)

\begin{tabular}{lcc}
\hline \multicolumn{2}{c}{$\begin{array}{c}\text { The scale of the talent recruitment and selection process over the past year and the change in the way } \\
\text { the company is managed and organized during the COVID-19 pandemic }\end{array}$} \\
\hline Correlation coefficients & Value & P-value \\
Kendall's tau-b & .430 & $<.001$ \\
Kendall's tau-c & .396 & $<.000$ \\
Spearman Correlation $r S$ & .507 & $<.000$ \\
\hline
\end{tabular}

Sources: developed by the authors.

P-values of the Kendall rank correlation coefficient, which measures the strength of the dependence between two rank variables and provides a nonparametric test of independence (i.e., the significance test), are lower than the selected significance level of 0.05 . Therefore, the null hypothesis is rejected. The difference between the coefficient calculated from the sample and zero is too large to result from random sampling alone. Thus, it is statistically significant, and there is a relationship between the variables. Based on these values, it is possible to verify hypothesis $\mathrm{H} 1$. Thus, there is a statistically significant relationship between the scale of the talent recruitment and selection process and the change in how the company is managed and organized during the COVID-19 pandemic.

Concerning the effort to verify the existence of a statistically significant relationship between the budget allocated to talent management at the time of the COVID-19 pandemic and the hunt for talent over the last year, a null and alternative hypothesis $\mathrm{H} 2$ were formulated:

$\mathrm{HO}$ (null hypothesis): $\theta=\theta 0$

$\mathrm{HO}$ : There is no statistically significant relationship between the budget allocated to talent management at the time of the COVID-19 pandemic and the talent hunting over the last year.

$\mathrm{H} 1$ (alternative hypothesis): $\theta=\theta$

$\mathrm{H} 1$ : There is a statistically significant relationship between the budget allocated to talent management at the time of the COVID-19 pandemic and the talent hunting over the last year.

Based on values of correlation coefficients (Table 4), it is impossible to verify (confirm) the hypothesis $\mathrm{H} 2$. Thus, there is a statistically significant relationship between the budget allocated to talent management at the time of the COVID-19 pandemic and the talent hunting over the last year. Therefore, hypothesis $\mathrm{H} 2$ is falsified.

Table 4. Results of testing hypothesis $\mathrm{H} 2$ (values of correlation coefficients)

\begin{tabular}{|c|c|c|}
\hline \multicolumn{3}{|c|}{$\begin{array}{c}\text { The budget allocated to talent management at the time of the COVID-19 pandemic and the talent } \\
\text { hunting over the last year }\end{array}$} \\
\hline Correlation coefficients & Value & P-value \\
\hline Kendall's tau-b & 8.169 & $<.417$ \\
\hline Kendall's tau-c & 3.366 & $<.909$ \\
\hline Spearman Correlation rS & 8.950 & $<.346$ \\
\hline
\end{tabular}

Sources: developed by the authors.

In times of pandemics, the support of TOP management in human resources management is necessary. Overall, the research indicates that more than half of HR managers agree or strongly agree that the organization they work for is negatively affected by the COVID-19 pandemic. More than half of respondents reported that the pandemic changed the management and organization of the company significantly. Indeed, many companies let some employees go in times of global crisis. The questionnaire 
survey results showed that most companies did not carry out any recruitment and selection during the pandemic. The competition for qualified talent has increased over the last year. More than $70 \%$ of HR managers agree while the budget for talent management has not changed much in the surveyed companies. Testing the statistically significant relationships verified hypothesis $\mathrm{H} 1 \mathrm{~d}$. It confirmed the existence of statistically significant relationships between the scale of the talent selection process over the past year and the change in management and organization of the company during the COVID-19 pandemic. On the other hand, hypothesis $\mathrm{H} 2$ was rejected. Thus, there were no statistically significant relationships between the budget for talent management in the organization during the COVID-19 pandemic and the competition for qualified talent for the last year.

Conclusion. As part of human resource management, talent management plays an important role in motivating, developing, and retaining talented and high-performing employees. Kavya Singh (2012) found that talent management has become an important and significant factor influencing the impact of globalization on human resource management in the era of globalization. Styblo (2010) states that several changes and trends affect human resources management, especially during the current global pandemic. That is why human resource management currently requires constant monitoring and compliance with standards. Businesses must promote international standards and follow current trends in HR. Despite the pandemic, employees expect the same conditions no matter where they are employed, whether it is the area of remuneration, benefits, provision of qualification development, etc. This unified human resources management service cannot do without advanced and well-connected information technology networks and global information systems. Talents must be convinced that the company they work for is unique and that the employee image plays an essential role. In a business environment affected by globalization, especially during the COVID-19 pandemic, innovation is a source of progress, and the same goes for the social sphere. Social innovation is a way of organizing work to increase productivity. In other words, it means greater flexibility in the work process and an increased share of people in decision-making - a style of work suitable for talented employees. Therefore, it is necessary to manage talents with a clear purpose in mind. Indeed, for successful and innovative businesses activity, managers should persuade employees to invest their time and resources in new and risky initiatives, manage issues arising from teamwork and employee engagement, and design and implement changes that will benefit their company.

Author Contributions: conceptualization, L. T., J.C. and N. S.; methodology, L. T. and J. C.; software, N. S.; validation, L. T., J. C., and N. S.; formal analysis, L. T.; investigation, J. C. and L. T.; resources, L. T.; data curation, J. C.; writing-original draft preparation, L. T., J. C. and N. S.; writing-review and editing, L. T.; visualization, N. S.; supervision, J. C. and N. S.; project administration, N. S.; funding acquisition, L. T.

Funding: This paper is an outcome of the scientific projects KEGA 012PU-4/2019, VEGA 1/0237/19, GAMA /20/1, and GAMA/20/6.

\section{References}

Beno, M. (2018). Working in the virtual world - an approach to the «home office» business model analysis. Ad Alta - Journal of Interdisciplinary Research, 8(1), 25-36. [Google Scholar]

Blatch-Jones, A., Nuttall, J., Bull, A., Worswick, L., Mullee, M., Peveler, R., ... \& Griffiths, G. (2020). Using digital tools in the recruitment and retention in randomised controlled trials: Survey of UK Clinical Trial Units and a qualitative study. Trials, 21, 1-11. [Google Scholar] [CrossRef]

Brad, F. (2019). 7 Talent Management Trends Worth Watching. Retrieved from [Link]

Caligiuri, P., De Cieri, H., Minbaeva, D., Verbeke, A., \& Zimmermann, A. (2020). International HRM insights for navigating the COVID-19 pandemic: Implications for future research and practice. Journal of International Business Studies, 51(5), 697-713. [Google Scholar] [CrossRef].

Camacho, P. (2020). 5 HR Trends Emerging in China During The Pandemic. Retrieved from [Link] 
L., Tomcikova, N., Svetozarovova, J., Coculova. Challenges and Priorities in Talent Management During the Global Pandemic Caused by COVID-19

Carnevale, J. B., \& Hatak, I. (2020). Employee adjustment and well-being in the era of COVID-19: Implications for human resource management. Journal of Business Research, 116, 183-187. [Google Scholar] [CrossRef]

Coculova, J., Svetozarovova, N., \& Bertova, D. (2020). Analysis of Factors Determining the Implementation of Talent Management.. Marketing and Management of Innovations, 3, 249-256. [Google Scholar] [CrossRef]

Collings, D. G., \& Mellahi, K. (2009). Strategic talent management: A review and research agenda. Human resource management review, 19(4), 304-313. [Google Scholar] [CrossRef]

Elliot, L. (2020). Prepare for the coronavirus global recession. The Guardian. Retrieved from: [Link]

Gigauri, I. (2020). Influence of COVID-19 Crisis on Human Resource Management and Companies Response: The Expert Study. International Journal of Management Science and Business Administration, 6(6), 15-24. [Google Scholar] [CrossRef]

Hanif, M. I., \& Yunfei, S. (2013). The role of talent management and HR generic strategies for talent retention. African Journal of Business Management, 7(29), 2827-2835. [Google Scholar] [CrossRef]

Kavya Singh, S. S. (2012). Driving forces and emerging challenges in talent management: A pathway to organizational success. International Journal of Advanced Research in Computer Science and Software Engineering, 2(6), 117-121. Retrieved from [Link]

KPMG. (2020). Potential impact of COVID-19 on the Indian Economy. Retrieved from [Link]

Mathur, R., \& Parashar, S. (2020). COVID-19: Managing talent in times of crisis. Retrieved from [Link

Nangia, M., \& Mohsin, F. (2020). Revisiting talent management practices in a pandemic driven VUCA environment-a qualitative investigation in the Indian IT industry. Journal of Critical Reviews, 7(7), 937-942. [Google Scholar] [CrossRef]

Nilsson, S., \& Ellstrom, P. E. (2012). Employability and Talent Management: Challenges for HRD Practices. European Journal of Training and Development, 36(1), 26-45. [Google Scholar] [CrossRef]

Ostertagova, E. (2013). Applied statistics. Košice: EQUILIBRIA s. r.o., 2013

Peirson, N., \& Paycor, V. (2020). COVID and the Future of Talent Management. Retrieved from [Link]

Richbell, S., Szerb, L., \& Vitai, Z. (2010). HRM in the Hungarian SME sector. Employee Relations, 32(3), 262. [Google Scholar] [CrossRef

Sonnenberg, M., van Zijderveld, V., \& Brinks, M. (2014). The role of talent-perception incongruence in effective talent management. Journal of World Business, 49(2), 272-280. [Google Scholar] [CrossRef]

Sparrow, P. R., \& Makram, H. (2015). What is the value of talent management? Building value-driven processes within a talent management architecture. Human resource management review, 25(3), 249-263. [Google Scholar] [CrossRef]

Styblo, J. (2010). World business management. Praha: Professional Publishing.

Tarique, I., \& Schuler, R. S. (2010). Global talent management: Literature review, integrative framework, and suggestions for further research. Journal of world business, 45(2), 122-133. [Google Scholar] [CrossRef]

Tomcíkova, L. (2020). Education and Development of Talented Employees in Relation to the Performance of Multinational Organizations with Regard to Globalization. Journal of Applied Economic Sciences, 3(69), 570-578. [Google Scholar] [CrossRef]

Yildirim, N., \& Korkmaz, Y. (2017). Challenge of Millennials in Project Management: Insights on Attitudes and Perceptions of Generation Y in Software Development Projects. International Journal of Information Technology Project Management, 8(2), 87-108. [Google Scholar] [CrossRef]

Люба Томчикова, Ph.D., Пряшівський університет, Словаччина

Нелла Свєтозаровова, Ph.D., Пряшівський університет, Словаччина

Яна Кокулова, Ph.D., Пряшівський університет, Словаччина

Проблеми та перспективи талант-менеджменту під час глобальної пандемії COVID-19

У статті проаналізовано перспективи та проблеми талант-менеджменту як одного з ефективних методів управління людськими ресурсами під час глобальної пандемії COVID-19. На основі узагальнення результатів дослідження встановлено, що талант-менеджмент як концепція управління трудовими ресурсами набуває свого поширення серед європейських компаній. Авторами зазначено, що питання управління кадровим потенціалом досліджуються як вітчизняними так і зарубіжними вченими. Підгрунтям дослідження стали результати онлайн-анкетування 137 менеджерів по роботі з персоналом, які працюють у національних та міжнародних компаніях Словаччини. У роботі сформовано дві гіпотези дослідження з метою визначення статистично значущого взаємозв'язку між: 1) масштабами набору та відбору перспективних кадрів та змінами в організаційно-управлінському стилі під час пандемії COVID-19; 2) між бюджетом, виділеним на підвищення кваліфікації працівників та методами підбору кадрів. У ході дослідження застосовано кореляційний аналіз та методи індуктивної статистики для перевірки сформованих гіпотез. Емпіричні результати засвідчили існування статистично значущого взаємозв'язку між масштабами набору та відбору перспективних працівників та змінами в організаційноуправлінському стилі під час пандемії COVID-19 (гіпотезу H1 - підтверджено). При цьому отримані результати дослідження підтвердили відсутність статистично значущого взаємозв'язку між бюджетом, що виділяється на підвищення кваліфікації працівників та методами підбору кадрів. 3 огляду на це, другу гіпотезу дослідження - відхилено. За результатами опитування оцінено вплив пандемії COVID-19 на роботу менеджерів з персоналу. Таким чином, враховуючи отримані результати, авторами виявлено зміни в управлінні кадровим потенціалом, а також визначено напрямки розвитку методів управління людськими ресурсами

Ключові слова: управління людськими ресурсами, пандемічна криза, управління кадровим потенціалом, таланти. 